\title{
PENGEMBANGAN PERANGKAT ASESMEN PRAKTIKUM DASAR-DASAR KIMIA ANALITIK BERBASIS KETERAMPILAN PROSES SAINS JURUSAN KIMIA UIN ALAUDDIN MAKASSAR
}

\author{
Wa Nirmala, Ramlawati ${ }^{1}$, Muhammad Danial ${ }^{2}$ \\ ${ }^{1,2}$ Dosen Program Pascasarjana Universitas Negeri Makassar \\ Email: kimia_nirmala@yahoo.co.id
}

\begin{abstract}
ABSTRAK
Ketercapaian tujuan pembelajaran dapat diukur dengan menggunakan asesmen pembelajaran. Dalam pembelajaran sains (praktikum) dibutuhkan asesmen yang baik dan terencana untuk menilai proses maupun hasil belajar mahasiswa. Oleh karena itu, dibutuhkan asesmen praktikum berbasis Keterampilan Proses Sains yang dapat mengukur aspek kognitif, psikomotorik dan sikap mahasiswa. Tujuan penelitian ini adalah mengembangkan dan memperoleh perangkat asesmen praktikum Dasar-Dasar Kimia Analitik berbasis Keterampilan Proses Sains (KPS) yang valid, relibel dan praktis. Jenis penelitian ini adalah penelitian pengembangan (Development Research) dengan menggunakan model pengembangan Plomp. Penelitian ini dilaksanakan di Laboratorium Kimia Fakultas SAINTEK UIN Alauddin Makassar dengan subjek penelitian adalah mahasiswa semester tiga sebanyak 42 orang. Teknik pengumpulan data melalui: 1) wawancara bebas; 2) pengamatan (observasi) dan asesmen langsung terhadap rancangan perangkat asesmen praktikum berbasis KPS; 3) dokumentasi dan 4) penyebaran angket dan lembar keterlaksanaan perangkat. Teknik analisis data dengan menggunakan analisis validasi ahli, analisis reliabilitas dan kepraktisan. Hasil penelitian yang diperoleh bahwa pengembangan dilakukan dalam lima tahap yaitu investigasi awal; perancangan; realisasi; tes, evaluasi dan revisi; dan implementasi serta perangkat asesmen praktikum berbasis KPS yang dikembangkan bersifat valid, reliabel dan praktis
\end{abstract}

Kata kunci: pengembangan plomp, asesmen praktikum, keterampilan proses sains.

\begin{abstract}
The achievement of learning objective can be measured by using learning assessment. In science learning (practicum), it needs good and planned assessment to assess the process as well as students' learning result. Therefore, practicum assessment with science process skill basis is needed which can measure the aspects of cognitive, psychomotor, and attitude of students. The study aims at developing and obtaining practicum assessment tools of analytic basic chemistry with science process skills basis which is valid, reliable, and practical. This study is development research using Plomp's development. The study was conducted in Chemistry Laboratory in Faculty of SAINTEK UIN Alauddin Makassar with the research subjects of the third semester students with the total of 42 students. Data were collected through 1) open interview, 2) observation and direct assessment on the design of practicum assessment tools with KPS basis, 3) documentation, and 4) questionnaire dissemination and tools implementation sheet. Data analysis technique used expert validation analysis, reliability analysis, and practicality. The result of the study reveals that the development was conducted in five stages, namely pre-investigation, designing, realization, test, evaluation and revision,
\end{abstract}


and implementation as well as the practicum assessment tools with KPS basis which was developed is valid, reliable, and practical.

Keywords: Plomp's development, practicum assessment, science process skills

\section{PENDAHULUAN}

Jurusan Kimia UIN Alauddin merupakan salah satu lembaga pendidikan di bawah naungan Kementerian Agama yang bertujuan untuk membekali mahasiswa dalam bidang kimia. Dalam membekali kompetensi lulusan, jurusan Kimia UIN Alauddin Makassar memiliki enam mata kuliah utama yang berperan penting dalam pencapaian Visi dan Misi Jurusan Kimia sehingga dalam pembelajaran kimia selalu menekankan pada kegiatan praktikum.

Praktikum kimia merupakan ciri khusus pembelajaran sains untuk memperoleh pengalaman laboratorium, dan keterampilan proses sains. Keterampilan proses sains merupakan suatu pendekatan pembelajaran yang mengarah pada pertumbuhan dan pengembangan sejumlah keterampilan tertentu pada diri peserta didik, agar mampu memproses informasi sehingga ditemukan hal-hal baru yang bermanfaat baik berupa fakta, konsep maupun pengembangan sikap dan nilai (Susilaningsih, 2012).

Wardani (2008), menyatakan bahwa melalui keterampilan proses sains, konsep yang diperoleh mahasiswa akan lebih bermakna karena keterampilan berpikir mahasiswa akan lebih berkembang. Hal ini juga dapat dilihat dalam penelitian Kruea-In, Nantarat dan Witat (2015), dan Hodosyova, et al. (2015) menyatakan bahwa, keterampilan proses sains (Science Procces Skill) dapat meningkatkan hasil belajar dimana mahasiswa dapat mencapai pengetahuan yang baik sebagai bagian dari ranah kognitif dan keterampilan investigasi sehingga keterampilan proses sains dapat mengembangkan kemampuan mengamati, menggolongkan / mengklasifikasikan, menaksir / menginterpretasikan, meramalkan, menerapkan, merencanakan penelitian, mengkomunikasikan yang dimiliki oleh mahasiswa.

Salah satu mata kuliah Kimia UIN Alauddin yang menggunakan praktikum sebagai metode pembelajaran adalah mata kuliah Dasar-dasar Kimia Analitik. Mata kuliah ini mewajibkan mahasiswa untuk memiliki keterampilan dalam menganalisis sampel kimia. Kompetensi dasar yang diharapkan muncul setelah peserta didik mengikuti praktikum Dasar-Dasar Kimia Analitik yakni menerapkan konsep dan prinsip metode analisis kualitatif dan kuantitatif. Berdasarkan studi pendahuluan yang dilakukan di Laboratorium Kimia Analitik Fakultas Sains dan Teknologi Universitas Islam Negeri Alauddin Makassar, pelaksanaan praktikum Dasardasar Kimia Analitik selama ini yang dimulai dari pelaksanaan kegiatan pra-lab, pengawasan dan penilaian proses (aktivitas) praktikum, serta penilaian laporan praktikum dilakukan oleh asisten laboratorium yang ditugaskan oleh dosen penanggung jawab mata kuliah. Dosen penanggung jawab bertugas mengontrol asisten. Kelemahan-kelemahan nampaknya terjadi dalam proses penilaian pra-lab, penilaian aktivitas dan penilaian laporan karena para asisten yang menangani praktikum atau percobaan tertentu memberikan penilaian tanpa menggunakan standar penilaian yang baku sehingga penilaian kognitif lebih diutamakan dan penilaian keterampilan kurang diperhatikan. Hal ini mengakibatkan penilaian seringkali bersifat subyektif dan sangat variatif.

Untuk mengukur kompetensi pengetahuan, keterampilan dan sikap ilmiah peserta didik dapat dilakukan dengan membuat perangkat asesmen praktikum. Perangkat asesmen merupakan rangkaian penilaian untuk memperoleh, 
menganalisis, dan menafsirkan data tentang proses dan hasil belajar peserta didik.

Penilaian kompetensi keterampilan peserta didik pada kegiatan praktikum dapat dilakukan melalui penilaian kinerja yang menuntut peserta didik mendemonstrasikan kompetensi tertentu (Permendikbud Nomor 66 Tahun 2013). Asesmen kinerja (Performance Assessment) adalah penilaian berdasarkan hasil pengamatan penilai terhadap aktivitas siswa sebagaimana yang terjadi. Penilaian dilakukan terhadap unjuk kerja, tingkah laku, atau interaksi siswa (Sa'dijah, 2009).

Berdasarkan latar belakang tersebut, maka penting untuk mengembangkan suatu perangkat asesmen praktikum berbasis Keterampilan Proses Sains (KPS) yang valid, reliabel dan praktis. Pengembangan asesmen praktikum berbasis KPS ini mengacu pada model pengembangan Plomp.

\section{METODE PENELITIAN}

Jenis penelitian ini adalah penelitian pengembangan (Development Research) model pengembangan Plomp yang terdiri dari lima fase yakni: (1) fase investigasi awal; (2) fase perencanaan; (3) fase realisasi (konstruksi); (4) fase evaluasi, tes, dan revisi; serta (5) fase implementasi. Penelitian ini dilaksanakan di Laboratorium Kimia Fakultas Sains dan Teknologi UIN Alauddin Makassar dan subjek penelitian adalah mahasiswa semester tiga Tahun Akademik 2016/2017 sebanyak 42 orang.

Penelitian ini dilaksanakan dalam beberapa tahap sebagai berikut: Tahap Investigasi Awal, di lakukan dalam empat tahap yaitu (a) Mengidentifikasi masalah. (b) Analisis masalah. (c) Membatasi masalah (d) Merencanakan kegiatan lanjutan. Tahap Perancangan (Desain), Pada tahap ini ditujukan untuk menghasilkan prototipe perangkat asesmen praktikum berbasis KPS pada praktikum Dasar-dasar Kimia Analitik. Tahap Realisasi (Konstruksi), Pada tahap ini dihasilkan draft awal hasil dari tahapan perancangan perangkat asesmen praktikum berbasis KPS. Tahap Tes, Evaluasi, dan Revisi, Pada tahapan ini dilakukan kegiatan validasi draft awal (Prototipe I) perangkat asesmen praktikum yang dikembangkan. Tahap Implementasi, Pada fase ini, setelah dilakukan evaluasi dan diperoleh Prototipe II yang sudah memenuhi kriteria valid maka produk tersebut dapat diimplementasikan.

Instrumen penelitian dikembangkan untuk memperoleh informasi tentang semua komponen kualitas pengembangan yang mencakup validitas, reliabilitas, dan kepraktisan. Untuk mendapatkan data informasi penelitian, teknik pengumpulan data yang digunakan ada empat meliputi: 1) wawancara bebas dengan asisten dan praktikan, 2) pengamatan dan asesmen langsung terhadap rancangan perangkat asesmen praktikum berbasis KPS pada praktikum Dasar-Dasar Kimia Analitik, 3) dokumentasi dan 4) pemberian angket dan lembar keterlaksanaan perangkat kepada asisten. Data yang telah dikumpulkan dengan menggunakan istrumen-instrumen diatas, selanjutnya dianalisis dan diarahkan untuk menjelaskan kualitas perangkat asesmen yang dikembangkan meliputi: valid, reliabel, dan paktis.

\section{HASIL DAN PEMBAHASAN}

1. Proses Pengembangan Perangkat Asesmen Praktikum

a. Tahap Investigasi Awal

1) Mengidentifikasi Masalah

Studi pendahuluan ini dilakukan melalui wawancara bebas terkait penilaian praktikum dengan asisten dan mahasiswa selaku praktikan. Kegiatan ini dilakukan dengan memberikan pertanyaan secara lisan kepada responden. Berdasarkan hasil wawancara dan pengamatan langsung diperoleh fakta-fakta pada Tabel 4.1

Tabel 4.1 Fakta yang Terjadi selama Praktikum Dasar-Dasar Kimia Analitik

\begin{tabular}{|c|l|c|}
\hline No & \multicolumn{1}{|c|}{ Fakta } & Keterangan \\
\hline 1 & $\begin{array}{l}\text { Asesmen praktikum tidak } \\
\text { menggunakan pedoman }\end{array}$ & Kekurangan \\
\hline
\end{tabular}




\begin{tabular}{|c|l|c|}
\hline & penilaian yang baku & Kekurangan \\
\hline 2 & Penilaian bersifat subjektif & Kelebihan \\
\hline 3 & $\begin{array}{l}\text { Penilaian pengetahuan } \\
30 \%, \text { keterampilan } 40 \% \\
\text { dan penilaian laporan 30\% }\end{array}$ & Kekurangan \\
\hline 4 & $\begin{array}{l}\text { Penilaian keterampilan } \\
\text { tidak menggunakan aspek } \\
\text { kinerja }\end{array}$ & $\begin{array}{l}\text { Kenilaian pengetahuan } \\
\text { tidak memiliki rubrik } \\
\text { penskoran. }\end{array}$ \\
\hline 6 & $\begin{array}{l}\text { Tidak menggunakan } \\
\text { penilaian sikap }\end{array}$ & Kekurangan \\
\hline 7 & $\begin{array}{l}\text { Penilaian laporan dinilai } \\
\text { per aspek }\end{array}$ & Kelebihan \\
\hline
\end{tabular}

2) Analisis Masalah

Tahap selanjutnya dalam investigasi awal yaitu menganalisis masalah yang telah ditemukan. Berdasarkan identifikasi masalah, analisis masalah dapat dikemukakan sebagai berikut:

a) Asisten dalam memberikan asesmen pra praktikum (pengetahuan) tidak menggunakan panduan penilaian.

b) Asisten tidak mempunyai pedoman penilaian keterampilan sehingga hanya menilai secara keseluruhan.

c) Asisten memberikan penilaian secara berkelompok sehingga tidak tergambar keterampilan praktikan.

d) Adanya ketidakseragaman dalam penilaian praktikum.

e) Asisten tidak meggunakan penilaian sikap selama praktikum

3) Membatasi Masalah

Berdasarkan identifikasi dan analisis masalah yang dilakukan, maka sangat diperlukan suatu asesmen yang dapat menilai pengetahuan kognitif, keterampilan dan penilaian sikap secara objektif pada kegiatan pra-praktikum, proses praktikum dan pasca praktikum. Berdasarkan keenam percobaan diatas, maka pembatasan masalah dilakukan pada perancangan perangkat asesmen praktikum berbasis keterampilan proses sains yang dapat menilai aspek kognitif, keterampilan dan sikap pada saat praktikum.
4) Merencanakan kegiatan lanjutan

Berdasarkan batasan masalah diperoleh kompetensi dasar yang diharapkan ada dalam praktikan (mahasiswa) setelah selesai praktikum. Kompetensi dasar ini disesuaikan dengan perangkat asesmen untuk menilai kompetensi praktikan (mahasiswa).

b. Tahap Perancangan

Perancangan perangkat asesmen praktikum berbasis KPS yang dilakukan yaitu:

1) Pra-Praktikum

Kegiatan pra praktikum merupakan prasyarat bagi praktikan (mahasiswa) untuk melaksanakan kegiatan praktikum. Aspek-aspek yang menjadi dasar dalam penilai meliputi pengetahuan tentang teori dan konsep, tujuan praktikum, dan prosedur kerja.

Tahap yang dilakukan pada perancangan asesmen pra-praktikum (pengetahuan) berbasis KPS yaitu:

a) Membuat kisi-kisi asesmen prapraktikum berbasis keterampilan proses sains

b) Menyusun tes (soal) berdasarkan indikator yang dicapai dan indikator KPS

c) Membuat rubrik penilaian, cara penilaian dan pengolahan skor prapraktikum

2) Kegiatan proses praktikum

Kegiatan ini merupakan inti dari pelaksanaan praktikum. Dimana praktikan dinilai keterampilannya sesuai dengan indikator KPS. Tahap yang dilakukan pada perancangan asesmen berbasis KPS pada proses praktikum yaitu:

a) Membuat kisi-kisi asesmen proses praktikum berbasis keterampilan proses sains

b) Menjabarkan aspek keterampilan yang dinilai sesuai dengan kisi-kisi yang telah dibuat

c) Membuat rubrik penilaian, cara penilaian dan pengolahan skor proses praktikum berdasarkan aspek keterampilan 
3) Kegiatan pasca praktikum

Kegiatan ini merupakan kegiatan akhir setelah praktikum dimana praktikan wajib melaporkan hasil praktikum yang telah dilakukan dengan mengikuti format baku dan aturan penulisan yang telah ditetapkan oleh Laboratorium Kimia UIN Alauddin Makassar.

Tahap yang dilakukan pada perancangan asesmen pasca (penilaian laporan) praktikum berbasis KPS yaitu:

a) Mendaftarkan aspek penilaian laporan yang dikembangkan

b) Membuat rubrik penilaian, cara penilaian dan pengolahan skor proses praktikum berdasarkan aspek laporan yang dinilai.

4) Penilaian sikap

Tahap yang dilakukan pada perancangan penilaian sikap yaitu:

a) Membuat kisi-kisi penilaian sikap berbasis KPS

b) Menjabarkan aspek afektif yang dinilai sesuai dengan kisi-kisi yang telah dibuat

c) Membuat rubrik penilaian, cara penilaian dan pengolahan skor proses praktikum berdasarkan aspek laporan yang dinilai.

\section{c. Tahap Realisasi}

Tahapan ini merupakan tahapan lanjutan dari kegiatan pada tahap perancangan. Pada tahap ini dihasilkan draft awal sebagai hasil dari perancangan perangkat asesmen praktikum berbasis KPS yang terdiri dari:

1) Perangkat asesmen pra-praktikum berisi pertanyaan menyangkut pengetahuan yang harus praktikan ketahui sebelum melakukan praktikum.

2) Perangkat penilaian proses praktikum berisi penilaian aspek keterampilan penggunaan alat dan bahan saat praktikum.

3) Perangkat penilaian laporan terdapat rubrik dan penilaian laporan praktikum.

4) Penilaian sikap
Pada penilaian sikap berisi penilaian aspek afektif praktikan selama melakukan kegiatan praktikum.

\section{d. Tahap Tes, Evaluasi dan Revisi}

Draf awal yang dihasilkan diberikan pada dua orang validator secara paralel. Dari hasil keduanya dijadikan bahan revisi. Hasil revisi pada draf awal dinamakan prototipe I. Penilaian para ahli berarti validator menelaah semua perangkat yang telah dihasilkan (draft awal) yaitu perangkat penilaian prapraktikum, proses praktikum, pasca praktikum, penilaian sikap, angket respon asisten dan lembar keterlaksanaan perangkat asesmen praktikum berbasis KPS. Hasil yang diperoleh selanjutnya dianalisis dengan validitas isi Gregory.

Djaali \& Muljono (2008)

berpendapat bahwa nilai validitas isi telah mencerminkan keseluruhan konten yang seharusnya dikuasai secara proporsional dilihat dari pendapat pakar atau ahli.

\section{1) Validasi dan Revisi Asesmen Pra- Praktikum \\ Perangkat asesmen pra-praktkum} berbasis KPS direvisi berdasarkan saran para ahli. Hasil revisi perangkat asesmen pra-praktikum (pengetahuan) disajikan pada Tabel 4.2

Tabel 4.2 Perbandingan Asesmen PraPraktikum Sebelum dan Setelah Validasi

\begin{tabular}{|c|l|l|}
\hline No & \multicolumn{1}{|c|}{ Sebelum Validasi } & \multicolumn{1}{|c|}{ Setelah Validasi } \\
\hline 1 & $\begin{array}{l}\text { Indikator seharusnya } \\
\text { menggunakan kata } \\
\text { operasional yang bisa } \\
\text { diukur }\end{array}$ & $\begin{array}{l}\text { Indikator telah } \\
\text { menggunakan kata } \\
\text { operasional yang bisa } \\
\text { diukur }\end{array}$ \\
\hline 2 & $\begin{array}{l}\text { Rubrik penilaian dinilai } \\
\text { per jawaban. }\end{array}$ & $\begin{array}{l}\text { Rubrik penilaian telah } \\
\text { dinilai per jawaban. }\end{array}$ \\
\hline
\end{tabular}

2) Validasi dan Revisi Asesmen Proses Praktikum Perangkat asesmen proses praktkum berbasis KPS direvisi berdasarkan saran para ahli. Hasil revisi perangkat asesmen proses praktikum (keterampilan) disajikan pada Tabel 4.3

Tabel 4.3 Perbandingan Asesmen Proses Praktikum Sebelum dan Setelah Validasi 


\begin{tabular}{|c|l|l|}
\hline No & \multicolumn{1}{|c|}{ Sebelum Validasi } & Setelah Validasi \\
\hline 1 & $\begin{array}{l}\text { Indikator seharusnya } \\
\text { menggunakan kata } \\
\text { operasional yang bisa } \\
\text { diukur }\end{array}$ & $\begin{array}{l}\text { Indikator telah } \\
\text { menggunakan } \\
\text { kata operasional } \\
\text { yang bisa diukur }\end{array}$ \\
\hline 2 & $\begin{array}{l}\text { Rubrik penilaian } \\
\text { dijabarkan sesuai aspek } \\
\text { yang dikerjakan }\end{array}$ & $\begin{array}{l}\text { Rubrik penilaian } \\
\text { telah dijabarkan } \\
\text { sesuai aspek yang } \\
\text { dikerjakan }\end{array}$ \\
\hline
\end{tabular}

3) Validasi dan Revisi Asesmen Pasca Praktikum

Perangkat asesmen pasca praktkum berbasis KPS direvisi berdasarkan saran para ahli. Hasil revisi perangkat asesmen pasca praktikum (penilaian laporan) disajikan pada Tabel 4.4

Tabel 4.4 Perbandingan Asesmen Pasca Praktikum Sebelum dan Setelah Validasi

\begin{tabular}{|c|l|l|}
\hline No & \multicolumn{1}{|c|}{$\begin{array}{c}\text { Sebelum } \\
\text { Validasi }\end{array}$} & \multicolumn{1}{|c|}{ Setelah Validasi } \\
\hline 1 & $\begin{array}{l}\text { Aspek penilaian } \\
\text { disesuaikan } \\
\text { dengan format } \\
\text { laporan. }\end{array}$ & $\begin{array}{l}\text { Aspek penilaian telah } \\
\text { disesuaikan dengan } \\
\text { format laporan. }\end{array}$ \\
\hline 2 & $\begin{array}{l}\text { Pada aspek } \\
\text { penilaian perlu } \\
\text { ditambahkan } \\
\text { aspek format dan } \\
\text { bahasa }\end{array}$ & $\begin{array}{l}\text { Pada aspek penilaian } \\
\text { telah ditambahkan } \\
\text { aspek format dan } \\
\text { bahasa }\end{array}$ \\
\hline
\end{tabular}

4) Validasi dan Revisi Penilaian Sikap

Perangkat penilaian sikap berbasis KPS direvisi berdasarkan saran para ahli. Hasil revisi perangkat penilaian sikap disajikan pada Tabel 4.5

Tabel 4.5 Perbandingan Penilaian Sikap

Sebelum dan Setelah Validasi

\begin{tabular}{|l|l|}
\hline \multicolumn{1}{|c|}{$\begin{array}{c}\text { Sebelum } \\
\text { Validasi }\end{array}$} & \multicolumn{1}{c|}{ Setelah Validasi } \\
\hline $\begin{array}{l}\text { Rubrik penilaian } \\
\text { sikap perlu } \\
\text { dioperasionalkan }\end{array}$ & $\begin{array}{l}\text { Rubrik penilaian sikap } \\
\text { telah dioperasionalkan }\end{array}$ \\
\hline
\end{tabular}

5) Validasi dan Revisi Angket Respon Asisten

Angket respon asisten direvisi berdasarkan saran para ahli. Hasil revisi angket respon asisten disajikan pada Tabel 4.6

Tabel 4.6 Perbandingan Angket Respon Asisten Sebelum dan Setelah Validasi

\begin{tabular}{|l|l|}
\hline Sebelum Validasi & \multicolumn{1}{c|}{ Setelah Validasi } \\
\hline Hilangkan butir & butir pernyataan angket yang \\
pernyataan angket & menimbulkan penafsiran \\
yang menimbulkan & ganda telah dihilangkan atau \\
penafsiran ganda. & diganti. \\
\hline
\end{tabular}

6) Validasi dan Revisi Lembar Pengamatan Keterlaksanaan Perangkat Lembar

Pengamatan Keterlaksanaan Perangkat direvisi berdasarkan saran para ahli. Hasil revisi lembar keterlaksanaan perangkat disajikan pada Tabel 4.7

Tabel 4.7 Perbandingan Lembar

Keterlaksanaan Perangkat Sebelum dan Setelah Validasi

\begin{tabular}{|l|l|}
\hline Sebelum Validasi & \multicolumn{1}{|c|}{ Setelah Validasi } \\
\hline Jangan memakai & Standar Ganda dalam \\
standar ganda & Penilaian telah \\
dalam penilaian. & dihilangkan \\
\hline
\end{tabular}

Hasil validasi perangkat asesmen praktikum oleh para ahli kemudian dianalisis dengan menggunakan analisis validitas isi Gregory. Hasil perhitungan validitas isi dirangkum dalam Tabel 4.8 Tabel 4.8 Deskripsi Validitas Isi Perangkat Asesmen Praktikum

\begin{tabular}{|c|l|c|c|}
\hline No & \multicolumn{1}{|c|}{$\begin{array}{c}\text { Penilaian } \\
\text { Validator }\end{array}$} & $\begin{array}{c}\text { Validitas } \\
\text { Isi }\end{array}$ & Kategori \\
\hline 1 & $\begin{array}{l}\text { Asesmen Pra- } \\
\text { Praktikum }\end{array}$ & 1,00 & Valid \\
\hline 2 & $\begin{array}{l}\text { Asesmen Proses } \\
\text { Praktikum }\end{array}$ & 1,00 & Valid \\
\hline 3 & $\begin{array}{l}\text { Asesmen Pasca } \\
\text { Praktikum }\end{array}$ & 1,00 & Valid \\
\hline 4 & Penilaian Sikap & 1,00 & Valid \\
\hline 5 & $\begin{array}{l}\text { Angket Respon } \\
\text { Asiten }\end{array}$ & 1,00 & Valid \\
\hline 6 & $\begin{array}{l}\text { Lembar } \\
\text { Keterlaksanaan } \\
\text { Perangkat }\end{array}$ & 1,00 & Valid \\
\hline \multicolumn{2}{|c|}{ Rata-Rata } & $\mathbf{1 , 0 0}$ & Valid \\
\hline
\end{tabular}

Berdasarkan hasil analisis validitas isi pada Tabel 4.8 diperoleh informasi bahwa semua perangkat yang dikembangkan telah memenuhi kriteria valid dimana diperoleh koefisien validitas isi keseluruhan perangkat asemen yang dikembangkan $>0,75$ atau $75 \%$. Hal ini berarti validator memberikan penilaian bahwa item-item pada perangkat asesmen yang dikembangkan telah memiliki 
relevansi terhadap apa yang hendak di ukur. Hal ini sesuai dengan yang dikemukakan Azwar (2012) bahwa validitas isi memastikan semua elemenelemen dalam perangkat tersebut benarbenar relevan dan telah mencakup keseluruhan domain yang hendak diukur.

\section{e. Tahap Implementasi}

1) Asesmen Pra-Praktikum Berbasis KPS

Asesmen pra-praktikum berbasis KPS merupakan asesmen mengenai pengetahuan awal mahasiswa sebelum memasuki praktikum. Asesmen prapraktikum terdiri atas 6 percobaan yaitu (1) Teknik Preparasi Sampel; (2) Analisis Kualitatif Anion; (3) Analisis Kualitatif Kation; (4) Titrasi Asidi-alkalimetri; (5) Titrasi Kompleksometri; dan (6) Analisis Gravimetri. Hasil ujicoba asesmen prapraktikum berbasis KPS dirangkum dalam Tabel 4.9

Tabel 4.9 Hasil Ujicoba Asesmen PraPraktikum

\begin{tabular}{|c|c|c|c|c|c|c|}
\hline \multirow{2}{*}{ Butir Soal } & \multicolumn{7}{|c|}{ Skor Rata-rata Percobaan } \\
\cline { 2 - 7 } & I & II & III & IV & V & VI \\
\hline $\mathbf{1}$ & 3 & 2 & 3 & 3 & 2 & 3 \\
\hline $\mathbf{2}$ & 3 & 3 & 5 & 3 & 3 & 3 \\
\hline $\mathbf{3}$ & 3 & 3 & 4 & 6 & 5 & 6 \\
\hline $\mathbf{4}$ & 2 & 2 & 2 & 2 & 2 & 2 \\
\hline $\mathbf{5}$ & 9 & 9 & 11 & 9 & 9 & 9 \\
\hline $\mathbf{6}$ & 3 & 3 & 3 & 2 & 3 & 3 \\
\hline
\end{tabular}

Asesmen Pra-Praktikum terdiri atas 6 butir soal dimana butir soal 1 sampai 3 tentang teori dan konsep; butir soal 4 tentang tujuan percobaan; butir soal 5 tentang prosedur kerja; dan butir soal 6 tentang pengetahuan agama. Skor maksimal dari setiap butir pada keenam percobaan berbeda-beda kecuali kor pada butir soal no 4 tentang tujuan percobaan.

Berdasarkan hasil ujicoba asesmen pra-praktikum (pengetahuan) berbasis KPS yang telah dijabarkan diatas, rata-rata mahasiswa (praktikan) telah mencapai indikator pembelajaran.

2) Asesmen Proses Praktikum Berbasis KPS

Asesmen proses praktikum berbasis KPS merupakan asesmen kinerja mahasiswa pada saat praktikum. Asesmen proses praktikum terdiri atas 6 percobaan dengan jumlah aspek kinerja yang berbeda setiap percobaan. Keseluruhan aspek kinerja memiliki skor maksimal 4. Untuk aspek kinerja utama pada setiap percobaan, skor yang diperoleh mahasiswa dikalikan dua sehingga skor maksimal pada aspek kinerja utama adalah 8 (Mansyur, et al., 2015). Hasil ujicoba asesmen proses praktikum berbasis KPS dirangkum dalam Tabel 4.10

Tabel 4.10 Hasil Ujicoba Asesmen Proses Praktikum

\begin{tabular}{|c|c|c|c|c|c|c|}
\hline \multirow{2}{*}{ Aspek Kinerja } & \multicolumn{6}{|c|}{ Skor Rata-rata Percobaan } \\
\cline { 2 - 7 } & I & II & III & IV & V & VI \\
\hline $\mathbf{1}$ & 8 & 3 & 3 & 3 & 3 & 3 \\
\hline $\mathbf{2}$ & 3 & 6 & 7 & 3 & 3 & 6 \\
\hline $\mathbf{3}$ & 3 & 3 & 5 & 3 & 2 & 3 \\
\hline $\mathbf{4}$ & 3 & 6 & 3 & 3 & 3 & 6 \\
\hline $\mathbf{5}$ & 7 & 3 & 4 & 3 & 3 & 7 \\
\hline $\mathbf{6}$ & 7 & 3 & - & 3 & 6 & 7 \\
\hline $\mathbf{7}$ & 6 & - & - & 7 & 6 & 3 \\
\hline $\mathbf{8}$ & 3 & - & - & 6 & 3 & 3 \\
\hline $\mathbf{9}$ & 4 & - & - & 3 & 4 & 6 \\
\hline $\mathbf{1 0}$ & - & - & - & 4 & - & 3 \\
\hline $\mathbf{1 1}$ & - & - & - & - & - & 4 \\
\hline
\end{tabular}

3) Asesmen Pasca Praktikum Berbasis KPS

Asesmen pasca praktikum berbasis KPS berupa penilaian laporan. Asesmen ini diujicobakan setelah kegiatan praktikum. Penilaian laporan yang dikembangkan terdiri dari 10 aspek yaitu 1) Pendahuluan; 2) Kajian Pustaka; 3) Metode Percobaan; 4) Hasil Pengamatan; 5) Reaksi (Jika ada); 6) Analisis Data (Jika ada); 7) Pembahasan; 8) Penutup; 9) Format; dan 10) Bahasa. Asesmen pasca praktikum terdiri atas 6 percobaan dengan jumlah aspek penilaian laporan yang berbeda setiap percobaan. Keseluruhan aspek penilaian memiliki skor maksimal 4 . Hasil ujicoba asesmen pasca praktikum berbasis KPS dirangkum dalam Tabel 4.11

Tabel 4.11 Hasil Ujicoba Asesmen Pasca Praktikum

\begin{tabular}{|c|c|c|c|c|c|c|}
\hline \multirow{2}{*}{ Aspek Laporan } & \multicolumn{6}{|c|}{ Skor Rata-rata Percobaan } \\
\cline { 2 - 7 } & I & II & III & IV & V & VI \\
\hline $\mathbf{1}$ & 3 & 3 & 3 & 3 & 3 & 3 \\
\hline $\mathbf{2}$ & 3 & 3 & 3 & 3 & 3 & 3 \\
\hline $\mathbf{3}$ & 3 & 3 & 3 & 3 & 3 & 3 \\
\hline $\mathbf{4}$ & 3 & 3 & 3 & 3 & 3 & 3 \\
\hline
\end{tabular}




\begin{tabular}{|c|c|c|c|c|c|c|}
\hline $\mathbf{5}$ & - & 3 & 3 & 3 & 3 & 3 \\
\hline $\mathbf{6}$ & - & - & - & 4 & 3 & 3 \\
\hline $\mathbf{7}$ & 3 & 2 & 3 & 3 & 3 & 3 \\
\hline $\mathbf{8}$ & 3 & 3 & 3 & 3 & 3 & 3 \\
\hline $\mathbf{9}$ & 3 & 3 & 3 & 3 & 3 & 3 \\
\hline $\mathbf{1 0}$ & 4 & 3 & 3 & 4 & 3 & 4 \\
\hline
\end{tabular}

\section{4) Penilaian Sikap}

Uji coba penilaian sikap dilakukan setiap pertemuan praktikum yang dimulai dari kegiatan pra-praktikum, proses praktikum dan pasca praktikum. Aspek afektif yang dinilai selama kegiatan prapraktikum yaitu: 1) Disiplin; 2) Santun; 3) Religius; Aspek afektif yang dinilai selama kegiatan proses praktikum yaitu 4) Jujur; 5) Teliti; 6) Kerjasama; 7) Tanggung Jawab; 8) Santun; 9) Religius. Aspek afektif yang dinilai selama kegiatan pasca praktikum yaitu 10) Jujur; 11) Disiplin; 12) Santun. Hasil ujicoba peniaian sikap disajikan pada Tabel 4.12

Tabel 4.12 Hasil Ujicoba penilaian Sikap

\begin{tabular}{|c|c|c|}
\hline No & Aspek Afektif & Skor Rata-rata \\
\hline \multicolumn{2}{|c|}{ Pra Praktikum } \\
\hline 1 & Disiplin & 3 \\
\hline 2 & Santun & 3 \\
\hline 3 & Religius & 3 \\
\hline \multicolumn{2}{|c|}{ Proses Praktikum } \\
\hline 4 & Jujur & 3 \\
\hline 5 & Teliti & 3 \\
\hline 6 & Kerja sama & 3 \\
\hline 7 & Tanggung jawab & 3 \\
\hline 8 & Santun & 3 \\
\hline 9 & Religius & 3 \\
\hline Pasca Praktikum & 2 \\
\hline 10 & Jujur & 3 \\
\hline 11 & Disiplin & 3 \\
\hline 12 & Santun & \\
\hline \multicolumn{3}{|c|}{} \\
\hline
\end{tabular}

Berdasarkan ujicoba penilaian sikap, skor rata-rata perolehan mahasiswa yaitu 3 kecuali pada jujur pada kegiatan pasca praktikum (jujur dalam menuliskan laporan), rata-rata skor yang diperoleh mahasiswa kurang yaitu 2. Hal ini disebabkan sebagian mahasiswa kurang jujur dalam menuliskan laporan atau kurang jujur dalam melaporkan hasil praktikum. Hasil ujicoba penilaian sikap menunjukan mahasiswa (praktikan) telah memenuhi aspek-aspek afektif yang dikembangkan.
5) Angket Respon Asisten

Hasil ujicoba penyebaran angket respon asisten disajikan pada Tabel 13

Tabel 4.13 Hasil Penyebaran Angket

Respon Asisten

\begin{tabular}{|c|c|c|c|}
\hline No & $\begin{array}{c}\text { Indikator } \\
\text { Angket }\end{array}$ & $\begin{array}{c}\text { Butir } \\
\text { Pernyataan }\end{array}$ & $\begin{array}{l}\text { Skor Rata- } \\
\text { rata }\end{array}$ \\
\hline \multicolumn{4}{|c|}{ Pra-Praktikum } \\
\hline \multirow[t]{2}{*}{1} & \multirow[t]{2}{*}{ Kepraktisan } & 1 dan 5 & 3 \\
\hline & & 4 & 4 \\
\hline 2 & Objektif & 2 dan 3 & 4 \\
\hline 3 & $\begin{array}{l}\text { Kesesuaian } \\
\text { dengan } \\
\text { indikator } \\
\text { dan KD }\end{array}$ & 6 & 3 \\
\hline \multicolumn{4}{|c|}{ Proses Praktikum } \\
\hline \multirow[t]{2}{*}{4} & \multirow[t]{2}{*}{ Kepraktisan } & 7 dan 10 & 3 \\
\hline & & 9 & 4 \\
\hline \multirow[t]{2}{*}{5} & \multirow[t]{2}{*}{ Objektif } & 12 & 3 \\
\hline & & 13 & 4 \\
\hline 6 & $\begin{array}{l}\text { Kesesuaian } \\
\text { dengan } \\
\text { indikator } \\
\text { dan KD }\end{array}$ & 11 & 3 \\
\hline \multicolumn{4}{|c|}{ Pasca Praktikum } \\
\hline 7 & Kepraktisan & $\begin{array}{l}14,16,17, \\
19 \text { dan } 20\end{array}$ & 3 \\
\hline 8 & Objektif & 18 & \\
\hline 9 & $\begin{array}{l}\text { Kesesuaian } \\
\text { dengan } \\
\text { indikator } \\
\text { dan KD }\end{array}$ & 15 & 4 \\
\hline
\end{tabular}

Berdasarkan Tabel 4.13, dapat dilihat skor rata-rata yang diberikan asisten yaitu 3 dan 4 dari skor maksimal 4 . Hal ini dapat disimpulkan bahwa para asisten merespon positif terhadap perangkat asesmen praktikum berbasis KPS yang dikembangkan.

6) Observasi Keterlaksanaan Perangkat Hasil penyebaran lembar keterlaksanaan perangkat asesmen disajikan pada Tabel 4.14

Tabel 4.14 Hasil Penyebaran Lembar

Keterlaksanaan perangkat Asesmen

\begin{tabular}{|c|l|c|}
\hline No & \multicolumn{1}{|c|}{ Aspek yang diamati } & $\begin{array}{c}\text { Skor rata- } \\
\text { rata }\end{array}$ \\
\hline 1 & $\begin{array}{l}\text { Asisten memberi respon } \\
\text { (tes) kepada praktikan }\end{array}$ & 3,7 \\
\hline 2 & $\begin{array}{l}\text { Asisten memberikan } \\
\text { penilaian berdasarkan } \\
\text { rubrik penilaian pra- } \\
\text { praktikum }\end{array}$ & 3,8 \\
\hline
\end{tabular}




\begin{tabular}{|c|l|c|}
\hline 3 & $\begin{array}{l}\text { Asisten mengamati kinerja } \\
\text { dan sikap praktikan } \\
\text { berdasarkan instrumen } \\
\text { asesmen kinerja }\end{array}$ & 3,7 \\
\hline 4 & $\begin{array}{l}\text { Asisten memberikan } \\
\text { penilaian berdasarkan } \\
\text { rubrik penilaian kinerja } \\
\text { berbasis KPS }\end{array}$ & 3,8 \\
\hline 5 & $\begin{array}{l}\text { Asisten memberikan } \\
\text { penilaian berdasarkan } \\
\text { rubrik penilaian afektif }\end{array}$ & 3,5 \\
\hline 6 & $\begin{array}{l}\text { Asisten memberikan } \\
\text { penilaian pada laporan } \\
\text { praktikum berdasarkan } \\
\text { instrumen penilaian } \\
\text { laporan }\end{array}$ \\
\hline
\end{tabular}

Berdasarkan Tabel 4.14 dapat dilihat skor rata-rata yang diberikan observer terhadap keterlaksanaan perangkat mencapai skor maksimal 4 sehingga dapat dinyatakan terlaksana secara keseluruhan.

Dari hasil uji coba pada tahap implementasi yang telah dilakukan dapat dilihat kualitas perangkat asesmen praktikum Dasar-Dasar Kimia Analitik berbasis KPS berupa validitas, reliabilitas dan kepraktisan.

2. Validitas, Reliabilitas dan Kepraktisan Perangkat Asesmen Praktikum

a. Validitas dan Reliabilitas

Perangkat asesmen praktikum Dasar-dasar Kimia Analitik yang telah dinyatakan valid oleh kedua validator berdasarkan koefisien validasi isi kemudian diujicobakan dan dihitung reliabilitas perangkat dengan menggunakan program SPSS Ver 20. Validitas dan Reliabilitas perangkat asesmen praktikum Dasar-dasar Kimia Analitik dapat dilihat pada Tabel 4.15 Tabel 4.15 Validitas dan Reliabilitas Perangkat Asesmen Praktikum

\begin{tabular}{|c|c|c|c|c|c|c|c|c|}
\hline \multirow[t]{4}{*}{ No } & \multirow{4}{*}{$\begin{array}{c}\text { Judul } \\
\text { Perco } \\
\text { baan }\end{array}$} & \multicolumn{7}{|c|}{$\begin{array}{c}\text { Validitas dan Reliabilitas Perangkat Asesmen } \\
\text { Praktikum }\end{array}$} \\
\hline & & \multicolumn{2}{|c|}{ Validitas } & \multicolumn{5}{|c|}{ Reliabilitas } \\
\hline & & \multirow{2}{*}{$\begin{array}{c}\text { Koef. } \\
\text { Valida } \\
\text { si }\end{array}$} & \multirow[t]{2}{*}{ Ket } & \multicolumn{4}{|c|}{ Koef. Alpha Crombach } & \multirow[t]{2}{*}{ Ket } \\
\hline & & & & Pra & $\begin{array}{l}\text { Pro } \\
\text { ses }\end{array}$ & $\begin{array}{c}\text { Pas } \\
\text { ca }\end{array}$ & $\begin{array}{c}\mathrm{Si} \\
\text { kap }\end{array}$ & \\
\hline 1 & $\begin{array}{c}\text { Tekni } \\
\text { k } \\
\text { Prepar } \\
\text { asi } \\
\text { Sampe } \\
1\end{array}$ & 1,00 & Valid & $\begin{array}{c}0,76 \\
9\end{array}$ & $\begin{array}{l}0 \\
, \\
9 \\
0 \\
9\end{array}$ & $\begin{array}{c}0,96 \\
4\end{array}$ & $\begin{array}{c}0,95 \\
6\end{array}$ & $\begin{array}{c}\text { Relia } \\
\text { bel }\end{array}$ \\
\hline
\end{tabular}

\begin{tabular}{|c|c|c|c|c|c|c|c|c|}
\hline 2 & $\begin{array}{l}\text { Analis } \\
\text { is } \\
\text { Kualit } \\
\text { atif } \\
\text { Anion }\end{array}$ & 1,00 & Valid & $\begin{array}{c}0,84 \\
4\end{array}$ & $\begin{array}{l}0 \\
5 \\
9 \\
5 \\
5\end{array}$ & $\begin{array}{c}0,98 \\
3\end{array}$ & $\begin{array}{c}0,99 \\
2\end{array}$ & $\begin{array}{c}\text { Relia } \\
\text { bel }\end{array}$ \\
\hline 3 & $\begin{array}{l}\text { Analis } \\
\text { is } \\
\text { Kualit } \\
\text { atif } \\
\text { Kation }\end{array}$ & 1,00 & Valid & $\begin{array}{c}0,72 \\
5\end{array}$ & $\begin{array}{l}0 \\
\text {, } \\
7 \\
2 \\
1\end{array}$ & $\begin{array}{c}0,95 \\
2\end{array}$ & $\begin{array}{c}0,97 \\
2\end{array}$ & $\begin{array}{c}\text { Relia } \\
\text { bel }\end{array}$ \\
\hline 4 & $\begin{array}{c}\text { Titrasi } \\
\text { Asidi- } \\
\text { Alkali } \\
\text { metri }\end{array}$ & 1,00 & Valid & $\begin{array}{c}0,87 \\
3\end{array}$ & $\begin{array}{l}0 \\
9 \\
9 \\
4 \\
9\end{array}$ & $\begin{array}{c}0,97 \\
7\end{array}$ & $\begin{array}{c}0,99 \\
2\end{array}$ & $\begin{array}{c}\text { Relia } \\
\text { bel }\end{array}$ \\
\hline 5 & $\begin{array}{l}\text { Titrasi } \\
\text { Komp } \\
\text { lekso } \\
\text { metri }\end{array}$ & 1,00 & Valid & $\begin{array}{c}0,87 \\
6\end{array}$ & $\begin{array}{l}0 \\
9 \\
9 \\
6 \\
9\end{array}$ & $\begin{array}{c}0,98 \\
2\end{array}$ & $\begin{array}{c}0,99 \\
0\end{array}$ & $\begin{array}{c}\text { Relia } \\
\text { bel }\end{array}$ \\
\hline 6 & $\begin{array}{l}\text { Analis } \\
\text { is } \\
\text { Gravi } \\
\text { metri }\end{array}$ & 1,00 & Valid & $\begin{array}{c}0,84 \\
4\end{array}$ & $\begin{array}{l}0 \\
6 \\
9 \\
3 \\
0\end{array}$ & $\begin{array}{c}0,95 \\
6\end{array}$ & $\begin{array}{c}0,97 \\
0\end{array}$ & $\begin{array}{c}\text { Relia } \\
\text { bel }\end{array}$ \\
\hline & ata-rata & 1,00 & Valid & $\begin{array}{c}0,82 \\
1\end{array}$ & $\begin{array}{l}0 \\
9 \\
9 \\
0 \\
5\end{array}$ & $\begin{array}{c}0,96 \\
9\end{array}$ & $\begin{array}{c}0,97 \\
8\end{array}$ & $\begin{array}{c}\text { Relia } \\
\text { bel }\end{array}$ \\
\hline
\end{tabular}

Berdasarkan nilai koefisien Alpha Cronbach pada analisis reliabilitas dengan bantuan program SPSS 20 yang disajikan dalam Tabel 4.15 perangkat asesmen praktikum berbasis KPS berada pada kategori reliabel karena nilai koefisien Alpha Cronbach-nya lebih besar dari 0,70 (Sukiman, 2012).

\section{b. Kepraktisan}

Analisis angket respon asisten digunakan untuk mengetahui kualitas kepraktisan perangkat yang dikembangkan. Perhitungan dan kategori hasil angket respon asisten dihitung sebagai berikut:

$\mathrm{Mi}=\frac{1}{2}($ skor maks + skor $\min )=$ $\frac{1}{2}(80+20)=50$

$$
\mathrm{SDi}=\frac{1}{6}(\text { skor maks }- \text { skor } \min )=\frac{1}{6}
$$

$(80-20)=10$

Kategori untuk menentukan kepraktisan perangkat dapat dilihat pada Tabel 4.16

Tabel 4.16 Kriteria Kepraktisan Perangkat Asesmen Praktikum

\begin{tabular}{|c|c|}
\hline Rentang Skor & Kriteria \\
\hline $65 \leq$ skor $\leq 80$ & Sangat praktis \\
\hline $50 \leq$ skor $<65$ & Praktis \\
\hline $35 \leq$ skor $<50$ & Cukup praktis \\
\hline $20 \leq$ skor $<35$ & Tidak praktis \\
\hline
\end{tabular}


Berdasarkan angket respon asisten yang diberikan kepada enam responden selaku asisten, hasil analisis angket respon asisten disajikan pada Tabel 4.17

Tabel 4.17 Hasil Analisis Angket Respon Asisten

\begin{tabular}{|c|c|c|}
\hline Responden & Skor & Kriteria \\
\hline A & 61 & Praktis \\
\hline B & 67 & Sangat Praktis \\
\hline C & 64 & Praktis \\
\hline D & 72 & Sangat Praktis \\
\hline E & 60 & Praktis \\
\hline F & 72 & Sangat Praktis \\
\hline Rata-Rata & 65.83 & Sangat Praktis \\
\hline
\end{tabular}

Observasi keterlaksanaan perangkat asesmen praktikum Dasar-dasar Kimia Analitik berbasis KPS oleh enam observer diperoleh nilai keterlaksanaan (T) sebesar 3,8. Hasil analisis obserbasi keterlaksanaan perangkat asesmen praktikum yang dikembangkan dapat dilihat pada Tabel 4.18

Tabel 4.18 Hasil Analisis Observasi Keterlaksanaan Perangkat Asesmen Praktikum

\begin{tabular}{|c|c|c|}
\hline Observer & Skor & Kriteria \\
\hline A & 3,3 & Terlaksana Keseluruhan \\
\hline B & 3,7 & Terlaksana Keseluruhan \\
\hline C & 3,7 & Terlaksana Keseluruhan \\
\hline D & 4,0 & Terlaksana Keseluruhan \\
\hline E & 3,8 & Terlaksana Keseluruhan \\
\hline F & 4,0 & Terlaksana Keseluruhan \\
\hline Rata-Rata & 3,8 & Terlaksana Keseluruhan \\
\hline
\end{tabular}

\section{KESIMPULAN}

Berdasarkan analisis hasil dan pembahasan yang telah dilakukan sebelumnya, maka dapat disimpulkan beberapa hal yang berhubungan dengan pengembangan perangkat asesmen praktikum Dasar-dasar Kimia Analitik berbasis KPS yakni: (1) Proses pengembangan perangkat asesmen praktikum berbasis KPS dilakukan dengan lima tahapan yakni tahap investigasi awal; tahap perencanaan; tahap realisasi atau konstruksi; tahap evaluasi, tes, dan revisi; serta tahap implementasi. (2) Perangkat asesmen praktikum Dasar-dasar Kimia Analitik berbasis KPS yang dikembangkan berdasarkan analisis validitas isi dan data uji coba, menunjukkan perangkat penilaian memenuhi kriteria valid, reliabel, dan praktis. Adapun nilai ratarata kevalidan, reliabilitas, dan kepraktisan berturut- turut adalah 1,00; 0,92; dan 65,83.

\section{DAFTAR PUSTAKA}

Azwar, Saifuddin. 2012. Reliabilitas dan Validitas Edisi Keempat. Yogyakarta: Pustaka Pelajar.

Hodosyova, Martina, Jana Útla, Monika Vanyová, Petra Vnuková, and Viera Lapitková. 2015. The Development of Science Process Skills in Physics Education. Procedia - Social and Behavioral Sciences, 186, 982-989.

Kruea-In, Chatchai, Nantarat Kruea-In and Witat Fakcharoenphol. 2015. A Study of Thai In-Service and PreService Science Teachers' Understanding of Science Process Skills. Procedia - Social and Behavioral Sciences, 197, 993-997. Mansyur, Harun Rasyid dan Suratno. 2015. Asesmen Pembelajaran di Sekolah, Panduan Bagi Guru dan Calon Guru. Yogyakarta: Pustaka Pelajar.

Sa'dijah, Cholis. 2009. Asesmen Kinerja dalam Pembelajaran Matematika. Jurnal Pendidikan Inovatif, (online) Vol. 4, No. 2 (http://jurnaljpi.files.wordpress.co m/2009, Diakses 13 September 2016).

Sukiman. 2012. Pengembangan Sistem Evaluasi. Yogyakarta: Insan Madani.

Susilaningsih, Endang. 2012. Model Evaluasi Praktikum Kimia Di Lembaga Pendidikan Tenaga Kependidikan. Jurnal Penelitian dan Evaluasi Pendidikan, (online) Vol. $16 \quad$ No. (https://download.portalgaruda.org /article.php?article $=52268 \&$ val $=44$ 8, Diakses 15 Maret 2016) 